\title{
Indonesia's National Strategic Project, Displacement, and the New Poverty
}

\author{
Sekar Banjaran Aji \\ Institute for Policy Research and Advocacy (ELSAM) \\ Email: sekarbanjaranaji@gmail.com \\ Achmad Firas Khudi \\ Chiang Mai University \\ Email: achmadfiraskhudi_a@cmu.ac.th
}

\begin{abstract}
The Government of Indonesia initiated the National Strategic Project comprising a wide range of infrastructure programs across the nation in 2016. The project as indicated by a set of supporting regulations and funding schemes. One of the project's supporting laws is the Presidential Decree No. 56/2017 on the mitigation of land procurement social impact. This study seeks to examine the impacts of Indonesia's national strategic project, focusing on socioeconomic deprivations and suggest relevant policy frameworks for the displaced population regarding their well-being and human rights. The desk review of displacement status and human rights will provide an analysis of displacement people's socio-economic condition and fundamental rights of displaced people from a selected district in which displacement has been occurring since 2016. The case study of the chosen community will elucidate the causes and consequences of this displacement case. We will utilize both qualitative and quantitative data taken from official government reports and affected residents.
\end{abstract}

Keywords: Displacement, Human Rights, and Poverty

\section{INTRODUCTION}

Government of Indonesia established Indonesia's National Strategic Project/Proyek Strategis Nasional (PSN) to accelerate economic growth and increase prosperity of the country. The project focuses on a huge range of infrastructure programmes across the nation. The government has noticed that this project has societal impact which they have to mitigate such as land acquisition and resettlement. Thus, by considering this impact, the government issued the Presidential Decree No. 56/2017 on the mitigation of social impact of land procurement. Preceding this presidential decree, Law No. 102/2016 on Land Procurement for Development for Public Interest in The Implementation of The National Strategic Project was issued to ensure land acquisition from people going smoothly. This law shows us that government has 
considered land procurement issue is one of major concerns in terms of infrastructure project. This law serves as an umbrella regulation for Indonesia's National Strategic Project.

Based on this law and its derivative regulation, the strategic project consists of 245 infrastructure development in many areas including road, train, airport, port, housing, energy, water and sanitation, dam, country's border post, and territorial development. Most of the strategic project are supported by business enterprises, both state-owned company and private company. There are several project cause problems because it is conflicting with other regulation. Project such as Yogyakarta's New Yogyakarta International Airport and South Sumatera's Light Rapid Transit are not included in Regional Spatial Planning of those provinces. ${ }^{1}$ But, the Law No.2/2012 underlined that land procurement must be conducted referring to Regional Spatial Planning.

More importantly, the implementation of the strategic project in New Yogyakarta International Airport created havoc among local residents. Several protest and resistance occurred to reject the airport development. Local residents advocated the devastating impacts of the project that cause job loss and unemployment as well as environmental and cultural degradation. In this regard, the project executor failed to facilitate the needs of affected people of land procurement. This problem reflects on how the policy implementation of the strategic project is quite authoritarian and executed on a very poor rule of law.

Against this backdrop, Indonesia's National Strategic Project is categorized as development-induced displacement and resettlement. It is because the project caused massive land relocation and violated human rights of affected people. These two factors have caused an impoverishment of the existing poverty. Impoverishment is the alienation of their substance that cause new poverty. It begins with landlessness and slowly turns into joblessness, loss of income, lack of access to health care and education and into other forms of deprivation. ${ }^{2}$

The strategic project will be analysed using a model of Impoverishment Risks, Risk Management, and Reconstruction (IRR). This model is intended for population displacement and resettlement, which developed by Michael M. Cernea. The model constitutes overall impoverishment process capturing the economic, social and cultural impoverishment, reflecting the fact that displaced people lose natural capital, man-made capital, human capital, and social capital. There eight risks which are typical interconnected trends defined as individual situations of displaced people. ${ }^{3}$ Three of eight risks, including landlessness, joblessness, and marginalization, are the focus of this article. Moreover, worldwide academic research has confirmed this

1 A Call for Solidarity: Supporting Struggle of Kulon Progo's Peasant in Fighting Airport and Airport City, by PWPP-KP (Paguyuban Warga Penolak Penggusuran - Kulon Progo) (Kulon Progo, Indonesia, 2017).

2 Prabhat Bhattacharya et al, "Development-Induced Displacement and Human Development Through Industrialisation in India” (2013) 2013 1-5.

3 Michael M Cernea, "Understanding and Preventing Impoverishment from Displacement: Reflections on the State of Knowledge *” (1995) 8:3 Journal of Refugee Studies 245-264 Keynote Address, International Conference on Development Induced Displacement. 
model, expanding its scope to include two additional risks: the loss of civil and human rights. ${ }^{4}$

Analysis of the strategic project will also be supported with concept of development as freedom from Amarthya K. Sen who underlined that development has to be more concerned with enhancing the lives we lead and the freedoms we enjoy. ${ }^{5}$ Sen explained this more in the counterpoint form of unfreedom, covering "the Lee thesis" that the denial of freedom stimulates economic growth and is good for rapid economic development. However, there is little evidence that authoritarian politics with the neglect of freedom actually helps economic growth. This thesis is very relevant with what the President of Indonesia planned in the strategic project.

From human rights perspective, the strategic project will be scrutinized from economic and social rights as well as the relation between business and human rights. Business enterprises should respect human right issues and seek to prevent or mitigate adverse human rights impact that are linked to their operations, products or services by their business relationships, even if they have not contributed to those impacts. ${ }^{6}$

\section{HUMAN RIGHT VIOLATION AND DEVELOPMENT-INDUCED DISPLACEMENT OF INDONESIA'S NATIONAL STRATEGIC PROJECT}

Indonesia's national strategic project is in the beginning process of implementation. In examining PSN, desk study is applied through literature review and secondary data analysis, while case study is utilized for analysing displaced people in microscale. A good literature review will be looking for a collection of sources that complement every specific context. Clearly defining themes for each context is important, otherwise research will not be sufficiently focused. But it is equally important to get a balance between knowing about your case-study area and knowing about key debates and approaches to your themes. ${ }^{7}$ Key debates and approaches in this article are through human rights and displacement analysis of affected residents. The New Yogyakarta International Airport (NYIA) construction in Kulon Progo District was taken as the case study of the overall Indonesia's national strategic project.

4. Theodore Downing, "Mitigating Social Impoverishment when People are Involuntarily Displaced(C) 1" (1996) 2 Understanding impoverishment: The consequences of developmentinduced displacement 33-48.

5 Amartya Sen, Development as Freedom, Development in Practice 10 (Oxford, 2000).

6 Guiding Principles on Business and Human Rights: Implementing the $U \boldsymbol{N}$ "Protect, Respect and Remedy" Framework, Report of the Special Representative of the Secretary General on the issue of human rights and transnational corporations and other business enterprises, by J Ruggie \& OHCHR, Report of the Special Representative of the Secretary General on the issue of human rights and transnational corporations and other business enterprises (2011).

7 Paula Meth \& Glyn Williams, "Literature Reviews and Bibliographic Searches" in Vandana Desai \& Robert Potter, eds, Doing Development Research, 3d ed (London: SAGE Publications, 2006) 560 . 
In the execution of PSN, the strategic project can be adjusted based on research of Committee of Acceleration for Prioritized Infrastracture/Komite Percepatan Infrastruktur Prioritas (KPIP). In Presidential Decree No. 58/2017, If the strategic project is not suitable with regional spatial planning, Ministry of Agraria and Spatial Planning needs to give recommendation to KPIP. At this point, land relocation issue is handled from central government institution who has a mandatory on it.

Coordinating Ministry of Economic Affairs is the leading actor in monitoring the implementation of the strategic project with support from the committee. The committee has to establish an information system for monitoring that links with ministry, central agency and local government. In this respect, those institutions give needed data to the committee. There is no explanation about what kind of data that the committee will provide 8 . It is urgent that data and information cover local residents who displaced from their homes. The displaced people of the strategic project are not part of main concerns. It can be seen from the policy and regulation to prevent and mitigate them which only one regulation, the Presidential Decree No. $56 / 2017$, compares to a lot of regulation which cover the implementation of the strategic project.

The interesting thing about Presidential Decree no. 56/2017 does not use the right approach to mitigate impacts in the project. It is very unfortunate, because without a human rights approach, the rules are just compensation that do not solve the problem. The human rights approach has many advantages. First, A human rights approach to development starts from the basic premise that the achievement of human rights is the objective of any process aimed at improving the human condition. It uses the various concepts associated with human rights, understood in their broadest sense as the scaffolding of development policy. The adoption of a rightsbased approach to development broadens the concept of governance and makes it necessary to add the qualifier "democratic" for it to make sense. As a consequence, the older and restricted conception of governance as efficiency in economic management has evolved into a broader understanding of the way in which leaders exercise power and authority in an effective and inclusive manner to advance the cause of human rights. Second, human right approach aims to analyse the implications of this shift for the realization of human rights, this article employs the concept of a "human rights risk." A human rights risk is simply the possibility that a human rights problem will adversely affect the interests of those persons undertaking an infrastructure project. Without a human rights-based approach, it is hard to ensure the right thing to do morally and legally.

Furthermore, the human right issue is reflected from the history of New Yogyakarta International Airport (NYIA)'s construction. President of Republic of Indonesia launched the NYIA on 27 January 2017. NYIA is constructed in Temon Sub-District. The project is a joint venture between PT Angkasa Pura I and GVK Power and Infrastructure, a company from India. As a result, villagers are affected and have been evicted in Glagah, Palihan, Sindutan, Jangkaran, Kebon Rejo and

8 Definition of data and information is not explained in the presidential decree. The presidential decree also did not come up with an attachment to further describe it contain. 
Temon Kulon villages. The airport construction displaces 2,875 households with 11,501 inhabitants, most of them make their living from agriculture and fishing sector. Hundreds of farmers have refused to accept the compensation packages on offer for land. Farmers, students and more than 84 social organizations gather into one movement to call for cancellation of the airport project. ${ }^{9}$ This movement also brings up an issue of law violation related to the absence of Environmental Impact Assessment (EIA). The EIA is not considered important by Governor of Yogyakarta according to report from affected residents because the process for the airport development plan in Kulon Progo has reached the payment of compensation, but an EIA study is just about to be carried out. This delayed EIA study plan is considered to have made the NYIA development process legally flawed. Based on Law Number 2 of 2012 concerning Land Acquisition for Development for Public Interest and Government Regulation Number 71 of 2012 concerning Implementation of Land Acquisition for Development for Public Interest, the EIA study should have been carried out before the issuance of the airport's IPL (Land Determination Permit). The basis for EIA must be in place before the IPL. The regulation explains that a land feasibility study in the form of an EIA must already exist before land acquisition occurs. The process for the airport development plan in Kulon Progo has reached the payment of compensation, but an EIA study is just about to be carried out. The process that has been carried out is legally flawed..$^{10}$ This is very important issue since the EIA is obliged by Indonesian law and serves as a tool to acquire environmental situation before executing project. The neglect of EIA in NYIA construction is relevant to be taken as an example of the preparatory implementation of national strategic project."

In implementing the EIA, it is a hybrid of national, international, and projectspecific legislation. The Environmental Impact Analysis is part of the tool for sees the environment as a 'precondition to the enjoyment of human rights'. Structurally, the EIA is a hybrid of national, international, and project- specific legislation. While EIAs are not currently required under international law or custom, most states have domestic laws requiring them for major infrastructure projects. ${ }^{12}$ While EIAs are not currently required under international law or custom, most states have domestic laws requiring them for major infrastructure project. ${ }^{13}$

9 Joint Statement of Attitude 80 civil society organizations / individuals. President Joko Widodo: Stop the Groundbreaking Plan for the Development of New Yogyakarta International Airport Kulonprogo (Press Release on January 26, 2017)

10 Nurul Kharismawati Kamaluddin, "Impact of The Airport Development Process in Kulon Progo" (2019) Universitas Muhammadiyah Yogyakarta.

11 https:/www.mongabay.co.id/2017/06/30/amdal-bandara-baru-di-kulon-progo-tak-layak-lanjutmengapa/

12 John H Knox, "The Myth and Reality of Transboundary Environmental Impact Assessment" (2002) 96 American Journal of International Law 291-319.

13 The enormous popularity of the domestic EIA provides a possible foundation for a global treaty on a transboundary EIA. 
Regardless of the source of the mandate for the EIA, the importance of conducting comprehensive impact assessments cannot be overstated. The purpose of an EIA compels its implementation in a way that accurately gauges impacts by identifying, predicting, evaluating, and mitigating physical, social, and other effects relevant to development proposals before principal decisions and commitments are made. ${ }^{14}$ The EIA's diagnostic function is particularly important for effective protection against claims of injustice made prior to environmental damage or during the construction and operation phases. ${ }^{1.5}$

Compliance with this instrument is the initial screening instrument before the EIA document assessed by the EIA commission. It is important to make an understanding of the spatial layout of all EIA stakeholders, especially the EIA commissions at the central, provincial and district/city levels. Article 4 of Government Regulation No. 27/2012 on Environmental Permit states that the location of the business plan and/or activity shall be in accordance with the spatial plan. In the event that the location of the business plan and/or activity is not in accordance with the spatial plan, the EIA document cannot be assessed and must be returned to the proponent. With the foundation of Government Regulation No. 26/2008 on National Spatial Plan in the document of Spatial Plan/Rencana Tata Ruang Wilayah (RTRW), there is a terminology of space structure and spatial pattern. More importantly, the review of the conformity of the location of the planned activities with the RTRW is to ensure the location of the activity plan is not within the clearly delineated protected area on the spatial pattern map. It is important that the type of business/activity and its location to be built is explicitly stated in the RTRW law.

There is a strange point, if we contrast those spatial law with Presidential Decree No. 58/2017. The location of the National Strategic Project is inconsistent with the Spatial Plan, the Regional Detailed Spatial Plan, or the Zoning Plan for Coastal Areas and Small Islands and is technically not possible to be moved from the planned location. Spatial adjustment can be made in accordance with the provisions of legislation in the field of spatial planning. To solve this, the Minister of Agrarian Affairs and Spatial may provide recommendations on the suitability of spatial planning over the location of the National Strategic Project which are not in accordance with the spatial plans of the regency/municipality and/or spatial plan national strategic areas referring to the provisions of the laws and regulations.

The implementation of NYIA construction also caused several problems over the period in Kulon Progo District. According to the 'Shadow Report on The Situation Of Human Right Defenders in Indonesia', Yogyakarta Sultan is the owner of the land. Thus, the land is 'leased' to the villagers, but it is still claimed by the Sultan and backed by controversial Indonesian law. ${ }^{16}$ This created conflicts when the Sultan is offered a more lucrative deal. This feudal system was supported by

14 Denise Christina de Rezende Nicolaidis, A Avaliaqdo de Impacto Ambiental: uma Anblise de Eficdcia [The Environmental Impact Assessment: an Analysis of Efficacy] at 28 (Dec. 2005) (unpublished dissertation, Universidade de Brasilia) (on file with author).

15 Ibid. at 32 n.17.

16 http://hrwg.org/wp-content/uploads/2016/11/6-UPR-Shadow-Report-on-the-Situation-of-HumanRights-Defenders-in-Indonesia-1.pdf. 
VOC/British colonist and is currently being revived under the special regional autonomy of Yogyakarta Sultanate. In contrast, residents who have been living and working there for decades have been supported by National Indonesian Agrarian Law. According to this Law No.5/1960 on Basic Agrarian Principles, residents have secured property rights and the management of the land. However, this law still applies in Indonesia, but it does not in Yogyakarta anymore. Yogyakarta Sultanate imposes to claim the land in the province as part of their asset. Even though the resistance occurred, the President Joko Widodo still conducted breaking ground on the project at the end of January 2017. In the breaking ground event, there was a massive wave of protest, including obstruction of the ground-breaking ceremony. Hundreds of farmers have refused to accept the compensation packages on offer for land. The movement protest was through marches, public campaigns, street art and direct-action including sit-in protest blocking a road with tree branches and stones, obstructing land surveys and removing boundary markers and four university students went on hunger strike. After the protest and demonstration that took place during 2014-2015, four farmers from Kulon Progo District were targeted following a demonstration against the development of the new airport, which would take over their homes and productive land. The four farmers, which are Sarijo, Wakidi, Tri Marsudi and Wasiyo, were sentenced to four months in prison for incitement and damaging property. ${ }^{17}$

The worst incidence occurred on 16 February 2016. Prior to the construction, people in the six villages were resisting against the construction of a two-metre-high security fence to block off the site and the police and army violently attacked the residents. ${ }^{18}$ Another peak of violence was on 27 November 2017 when a video posted by Jogja Darurat Agraria showed how 400 public authorities cut off electricity supplies from villager's houses and used bulldozers to destroy some houses as well as uprooted trees and plants. Villagers and students including women, men and children resisted and tried to block and lay in the path of the bulldozers. After that, they were dragged away by public authority. On 5 December 2017, the police arrested 12 activists from the solidarity network in the area. Violence against citizens happened again on 8 January 2017. At least 15 residents and volunteers were victimized, and two of them were rushed to the hospital due to injuries caused by the police. ${ }^{19}$ Despite of the land acquisition conflict, Kulon Progo District is located on the southern coastal area of Yogyakarta Province. This place is one of the most important natural reservations in Java island. The district's area is included in the list of 14 sand dunes in the world that have special functions in reducing the danger of tsunami threat, intrusion prevention or seawater infiltration to groundwater layer, and inhibit erosion of coastal

17 Joint Statement of Attitude 80 civil society organizations / individuals. President Joko Widodo: Stop the Groundbreaking Plan for the Development of New Yogyakarta International Airport Kulonprogo (Press Release on January 26, 2017)

18 https://antiaero.org/tag/kulon-progo-airport/

19 Pramilla Deva. 2018. Flight-path farmers pushed out New Internationalist magazine, published in September 2017 https://newint.org/ 
land.$^{20}$ From this situation, NYIA development has certainly plunged local residents into abject misery.

In addition to NYIA project, 30 projects are filtered as priority project of the PSN's implementation. KPIP also reported that of 245 projects will require an estimated of total financing of Rp. 3,197 trillion with the sources from state budget amounting to Rp. 525 trillion, state owned enterprise amounting to Rp. 1,258 trillion, and private company amounting to Rp. 2,414 trillion. The huge amount of private funding in here is due to the revision of Presidential Decree No. 58/2017 in Article 2 Paragraph 4, that financing in the construction of PSN can also be done through non-government budget under the coordination of Minister of National Development Planning.

Against this background, NYIA construction is clearly classified as developmentinduced displacement which happened because of the infrastructure project, beside its impact on human rights. Development-induced displacement is one of four root causes of internal displacement, others are conflict-induced displacement, environmentally induced displacement, and disaster-induced displacement. Affected persons who are forced to displace entitled with a name of "internally displaced persons" (IDPs). This term is utilized in international instruments and agreements. Research on displacement has shifted over the period from being stress-centred to impoverishment-centred..$^{21}$ The most recent and applicable impoverishment-centred concept is Impoverishment Risks, Risk Management, and Reconstruction (IRR). Prior to IRR, stress-centred concept of displacement was popularly called the Scudder-Colson temporal model of resettlement phases. The IRR model itself has four functions, two of them are used in this article including predictive function and planning, problem-resolution function.

In tackling displaced persons, the IRR model utilizes 8 risks as its main features. Those risks are landlessness, joblessness, homelessness, marginalization, increased morbidity, food insecurity, loss of access to common property, and social disarticulation. The model explains the displaced people from multi perspective of capabilities and can be defined as unfreedom. ${ }^{22}$ The unfreedom is deprivation of freedom. This deprivation of freedom happened because of the denial of right. Many people in the world are systematically denied political liberty and basic civil rights. It is sometimes claimed that the denial of these rights helps to stimulate economic growth and is good for rapid economic development ${ }^{23}$. It is also supported by the empirical fact that human right violations hinder the economic growth. Other findings explain that elements of all groups of human rights are a precondition for making

20 https://ejatlas.org/conflict/international-airport-on-the-kulon-progo-coast-indonesia

21 Bogumil Terminski, Development-Induced Displacement and Resettlement: Theoretical Frameworks and Current Challenges (Development, 2013).

22 Sen, supra note 5.

23 The denial of these rights is a thesis known as "the Lee thesis," attributed in some form to the former prime minister of Singapore Lee Kuan Yew, is sometimes backed by some rudimentary empirical evidence. In fact, more comprehensive intercountry comparisons have not provided any confirmation of this thesis, and there is little evidence that authoritarian politics helps economic growth. 
productive use of one's resources and are thus efficiency-enhancing. Basic human rights have indeed a positive effect on investment and productivity. ${ }^{24}$ That is why it is irrelevant to overly accelerate economic growth without focus on the basic human rights.

Furthermore, there are 3 displacement risks including landlessness, joblessness, and marginalization in NYIA development. Landlessness is removal of land which expropriates the main foundation upon benefit from people's productive systems, commercial activities and livelihoods. It caused loss of both physical and man-made capital which form de-capitalization and pauperization of displaced people. Physical relocation resulted in unemployment or underemployment of urban and rural people who are displaced landless labourers, service workers, artisans, and small businessmen. Joblessness as one of the IRR's focus explains employment status of displaced people. Marginalization also occurred in displaced area when families lose economic power and slide downwards. They are transformed into small landholders, small shopkeepers, and workers and continued to downsize and slip below poverty thresholds. The displaced people of NYIA project are described on this following table:

Table 1. The Impoverishment Risks of New Yogyakarta International Airport Construction

\begin{tabular}{|c|c|c|c|}
\hline Sector/Description & Landlessness & Joblessness & Marginalization \\
\hline $\begin{array}{l}\text { Agriculture/Sponge } \\
\text { gourd }\end{array}$ & $\begin{array}{l}60 \\
\text { ton/hectare/year }\end{array}$ & $\begin{array}{l}12,000 \\
\text { agriculture } \\
\text { workers }\end{array}$ & \multirow{5}{*}{$\begin{array}{l}\text { Displacement } \\
\text { caused } \\
\text { economic, social, } \\
\text { and } \\
\text { psychological } \\
\text { marginalization } \\
\text { on farmers in } \\
\text { those agricultural } \\
\text { field. } .^{25} \text { The } \\
\text { affected farmers } \\
\text { of economic } \\
\text { marginalization } \\
\text { are ranging from } \\
4,000 \text { to } 60,000 .\end{array}$} \\
\hline Agriculture/Melon & $\begin{array}{l}180 \\
\text { ton/hectare/year }\end{array}$ & $\begin{array}{l}60,000 \\
\text { agriculture } \\
\text { workers }\end{array}$ & \\
\hline Agriculture/Watermelon & $\begin{array}{l}90 \\
\text { ton/hectare/year }\end{array}$ & $\begin{array}{l}60,000 \\
\text { agriculture } \\
\text { workers }\end{array}$ & \\
\hline Agriculture/Eggplant & $\begin{array}{l}90 \\
\text { ton/hectare/year }\end{array}$ & $\begin{array}{l}12,000 \\
\text { agriculture } \\
\text { workers }\end{array}$ & \\
\hline Agriculture/Chili & $\begin{array}{l}30 \\
\text { ton/hectare/year }\end{array}$ & $\begin{array}{l}4,000 \\
\text { agriculture } \\
\text { workers }\end{array}$ & \\
\hline
\end{tabular}

24 Lorenz Blume \& Stefan Voigt, "The Economic Effects of Human Rights” (2007) 60:4 Kyklos 509538.

25 Terminski, supra note 21. 


\section{Source: Paguyuban Warga Penolak Penggusuran - Kulon Progo, 2017}

It is clear that the current national strategic project matches with the displacement model. NYIA construction is part of transportation development. Transportation development is the second main cause of development-induced displacement in the worldwide after dam development. Speaking of development induced displacement in Indonesia, there was an experience of Saguling Dam Construction which displaced local inhabitants at Bongas and Sarinage Villages. This experience resulted in less preferable and beneficial occupation, increased unemployment, even though improved living conditions. Unemployment in Bongas and Sarinage have deteriorated at the level of $23.7 \%$ and $14 \%$ after the dam construction. The improved living conditions at their present settlement was due to better access to basic facilities including electricity, drinking water, and school facilities. ${ }^{26}$ This research proved that joblessness is the most pertinent and overarching to the overall impoverishment risks. If we put in NYIA context, farmers who will be displaced and shifted their work need to be ensured that the new occupations are commensurate with the previous ones. It is a very challenging condition for farmers whose land will be taking over for construction project to find a new field for agriculture.

Needless to say, the NYIA area will be designed to such aero city where several areas area reoriented to support its airport function. It in turn causes more displacement because many areas will be constructed to support the airport such as recreational and logistical area, transportation, and industry. Establishment of NYIA will only spur such benefit for formal works and high-income people. However, farmers and other agricultural workers will not get sufficient benefits from the NYIA. It is also reflected from past experience on airport construction that happened in India at Navi Mumbai Airport Project (NMIA) and Cochin International Airport Limited (CIAL). This following situation is relatively similar with displacement takes place in Kulon Progo. A study on NMIA displacement found that farming and fishing community suffer from loss of land, ancestral occupation, and property. In CIAL construction, most of affected people have lost their agriculture land with the percentage of $31 \%$, land used for brick construction with the percentage of $22 \%$, after the displacement. ${ }^{27}$

\section{INDONESIA'S NATIONAL STRATEGIC PROJECT AND THE NEW POVERTY: IMPACT AND POLICY FRAMEWORK IN SUSTAINABLE CONTEXT}

Development-induced displacement unleashes widespread social, economic and environmental changes that follow well-established patterns. Although they vary in severity, these patterns are remarkably consistent regardless of what type of project or industry is responsible for the displacement. Development of NYIA and overall

\footnotetext{
26 Sunardi et al, "Livelihood status of resettlers affected by the Saguling Dam project, 25 years after inundation” (2013) 29:1 International Journal of Water Resources Development 25-34.

27 TV Aneesh \& R R Patil, "Development and Displacement in Kerala: An Experience of Cochin International Airport Limited (CIAL)” (2015) 11:10 European Scientific Journal, ESJ.
} 
PSN can improve the level of poverty at local level. According to CIAL and NMIA experience, PSN impact on people will also follow the same path. It will certainly deteriorate the unemployment status of the low-income groups, especially agriculture workers. The cause of new poverty has not been measured yet by Government of Indonesia. Government of Indonesia have not also designed a sufficient compensation programme to overcome the displacement effect and its impact on poverty.

Joblessness, landlessness, and marginalization, which are three risks of displacement, serve as intervening variables that enlarge the new poverty. Unemployment will appear after displacement since affected residents have to shift their occupation, particularly jobs related to land such as agriculture worker. Farmers in Kulon Progo District are good example of this problem. Furthermore, postdisplacement unemployment or underemployment is often chronic following the dismantling of the local income-generating resource base. ${ }^{28}$

In terms of landlessness, evidence of the new poverty is surfacing in displacement studies throughout the world but is well illustrated by pre/post displacement research on those forcefully resettled by six infrastructure projects in the State of Orissa in eastern India. Following displacement, landlessness increased in all six populations, reaching up to five times its pre displacement rates. Displacement in Orissa is comparable with PSN as the displacement is also massive occurred in six sites. The risk of marginalization also threatens displaced individuals and entire communities as they slip into lower socio-economic status relative to their local areas. Research has shown that such marginalization is accompanied by a loss in self-esteem, especially when the displaced become "outsiders" and "newcomers" in host communities.

The displacement risks and human right problems will affect the sustainability of development in Indonesia. Displacement and human right issues approximated under SDGs 10 Reduced Inequality as well as SDGs 16 Peace and Strong Institution. It is because displacement and human right related to forced migration and freedom that accommodated under SDGs target 10.7 on migration policy and SDGs target 16.10 on freedom protection. Thus, the sustainable development goals (SDGs) implementation particularly in those targets will be hampered and difficult to achieve.

In terms of policy framework, Presidential Decree Number 102 of 2016 specifically in Article 23 mentions the government may provide guarantees against risks that may arise from the delay in budgeting for land procurement carried out by the Ministry/Institution as the Project Responsible for Cooperation with Business Entities, whereby the government appoints the Infrastructure Guarantee Agency to carry out the guarantee in accordance with the provisions of the regulation. The agency is the State Asset Management Agency as Public Service Agency under the

28 Downing, supra note 4.

29 Theodore Downing, “Creating poverty: The flawed economic logic of the world bank's revised involuntary resettlement policy" (2002) 12 Forced Migration Review 13-14; Theodore Downing, "Avoiding new poverty: Mining induced displacement and resettlement" (2002) 1 IDNR- Global Network in Displacement and Resettlement Research 5-8. 
Directorate General of State Assets, Ministry of Finance held a meeting titled Synergy of Acceleration of Land Procurement Funding for National Strategic Project.

In coordinating the government agencies, President Joko Widodo instructed the Coordinating Minister for Political, Legal and Security to implement presidential instruction of PSN through corresponding with the Attorney General, Chief of Police of the Republic of Indonesia, and Minister of Administrative Reform and Bureaucracy Reform to prepare provisions on procedures or Standard Operating Procedures (SOP). The SOP relates to the calling and examination of government officials for the small medium enterprises or business entities by the Prosecutor and the Police on reports of cases of irregularities in the acceleration of implementation of national strategic project. In addition to the SOP, the presidential instruction stated that the Minister of Home Affairs is involved.

First, the Minister of Home Affairs shall supervise governors, regents, and mayors and impose sanctions on them who do not provide support in accordance with the provisions of legislation. Second, the Minister of Home Affairs also conducts an evaluation of local regulations that impede and incur high costs of implementing national strategic project. Third, the Minister of Home Affairs cancels the local regulations that hinder the implementation of national strategic project based on the results of project evaluation. Moreover, the presidential instruction also constitutes that the governors, regents, and mayors to be obliged to support the acceleration of the implementation of national strategic project in their respective regions through socialization to the community in supporting land acquisition and price control of the land. Local regulation can be also revised to ensure and support the accomplishment of the national strategic project. In regards of doing this, Coordinating Minister for Economic Affairs reports to the President at least once in six months or at any time required.

In the Presidential Decree No.56/2017, it is also interesting to oversee that compensation package is stated as charitable fund/uang santunan. This term is peculiar since the government actually buy the land from residents and not merely take and compensate with charitable fund. The presidential decree has not also emphasized that relocation will cause economic impact. It only mentioned that PSN will affect social field. In here, we can see that the government try to reduce the real impact of PSN by defining the impact as social problem only. As a matter of fact, the relocation will noticeably increase the loss of economic opportunities based on displacement experience in several countries. In Uganda, displaced households experienced an initial decrease in consumption of between $28 \%$ and $35 \%$, as well as a $1 / 2$ standard deviation decrease in the value of assets compared to nondisplaced households. ${ }^{30}$

In tackling affected people of the strategic project, Government of Indonesia proposed a scheme to implement compensation programme. KPIP provides compensation scheme that facilitates affected people with amount of money. Compensation package was mentioned in Article 5 Presidential Decree No. 56/2017

30 The Economic Consequences of Forced Displacement, HiCN Working Paper, by Nathan Fiala, HiCN Working Paper 137 (Households in Conflict Network, 2009). 
including house dismantlement, mobilization, house rent, and compensation allowance. It has not been mentioned that compensation package has to meet the needs of people and equally fulfil their loss. This compensation package is not an ideal offer for displaced people. The main principle of compensation was "land for land”, i.e., dispossessed land rights holders could receive an equal amount of land in the new settlement which in principle corresponded to their land loss. ${ }^{31}$

The administration of compensation programme comprises of several procedures. The minister who carries out government affairs in the field of state finance is formally responsible for planning budgeting and disbursement of the loss to the eligible entity in the matter of land acquisition using the fund of the enterprise first, upon the proposal of the minister/head of state own enterprises. While the Minister and the leaders of state owned enterprises are responsible for the planning of the needs and the submission of repayment funds, the Minister of Agrarian Affairs and Spatial Planning is responsible for the implementation of Land Acquisition in accordance with the provisions of legislation in the field of Land Procurement for development for the public interest.

Compensation by itself cannot adequately restore and improve the income levels and livelihood standards of people subjected to expropriation and forced displacement. Examining these problems, specialists conclude that involuntary resettlements have been persistently under-funded and dislocated people persistently undercompensated. ${ }^{32}$ Asset replacement through compensation does not prevent affected people from being worse off. The disruptive process of displacement leads IDPs into playing "catch up," and assets must be created through investment in ways to re-establish income streams and build wealth. The root cause of this problem is the basic incompatibility between goals (restoring and improving incomes) and means (compensation for losses). The goals are inherently condemned to remain most often and chronically unreachable. ${ }^{33}$

Compensation programme is regulated by Presidential Decree No. 56/2017, that ministries/agencies, local governments, state-owned enterprises or regional-owned enterprises whose land will be used for the construction of National Strategic Project and controlled by the community/, have to prepare a document on social impact management plan. The document of the social impact management plan shall at least contain: a) the location of the land, the area and condition of the land which is controlled by the community; b) data of people who control the land; and c) an overview of the situation and condition of the people who control the land. The document of the social impact management plan shall be submitted to governor. After receiving the document of the social impact management plan, the governor shall establish an Integrated Team for Social Impact Management.

31 Pham Huu Ty, A C M Van Westen \& Annelies Zoomers, "Compensation and Resettlement Policies after Compulsory Land Acquisition for Hydropower Development in Vietnam: Policy and Practice" (2013) 2:4 Land 678-704.

32 Michael M Cernea, The Economics of Involuntary Resettlement: Questions and Challenges (Washington DC: The World Bank, 1999).

33 Cernea, supra note 3. 
To date, there is no further description about the work of integrated team and its compensation programme given to affected people. Members of majority inhabitants should crucially receive reasonable protection in law and policy frameworks in resettlement programme. ${ }^{34}$ The resettlement programme must be elevated to encompass collaboration and involvement in decision making instead of merely consultation and involvement in the execution of plans. In such cases, affected people are able to join a resettlement committee and participate in decision making or in designing resettlement programmes.

Resettlement programme in Vietnam is one of good experience in tackling displacement issue. In A Luoi hydropower project, the investor first hired a consultation company to prepare a master plan for compensation, assistance, and resettlement for submission to Provincial People's Committee (PPC) for approval. PPC continued to establish a management board to implement the ground clearance, compensation, assistance and resettlement (BCAR) process at district level. BCAR served as steering committee where leaders of the district, finance, department, and hydropower company were represented. Department of Natural Resources and Environment (DONRE), a mandated ministry for environmental project in Vietnam, was responsible for mapping, land and property inventory, and land use certificate allocation.

Commune leaders and representatives within the commune of the Fatherland Front Committee worked as a bridge between the BCAR board and affected households; they organised meetings with households to announce the details of land recovery, explained compensation and resettlement policy as well as persuaded people to accept the plan. Only one villager was invited to join the BCAR board; he was the village head who was also a district official. This pre-displacement process is considerably successful in contrast with the pre-displacement process in Kulon Progo's airport. It is because government officials and business enterprises should not merely respect the right of affected people, they should also pay attention to the participation of affected people in arranging resettlement programme helps diminish adverse effect and severe vulnerability. Thus, the resettlement programme enhances the chance of success for displaced people to adopt to new places.

A Luoi Hydropower's displacement can be taken as the good experience of relocating local residents. The process of moving resident to new place is more democratic, decent, and humane. Resettlement in Kulon Progo and PSN at large should acquire a great support from people and involve more participation of local resident in affected areas. Policy framework for social impact of PSN has to take an account more people aspiration as well as social-economic problems through evidence-based data of affected residents. As a result of doing this, the adverse impact of relocation caused by PSN can be reduced and local development will be more sustainable.

34 Joint Statement of Attitude 80 civil society organizations / individuals. President Joko Widodo: Stop the Groundbreaking Plan for the Development of New Yogyakarta International Airport Kulonprogo (Press Release on January 26, 2017) 
Additionally, businesses play an important role in the relocation issue particularly in human rights policy. In 2011, businesses were provided with operational guidance on the implementation of their corporate responsibility to protect human rights in the Guiding Principles on Business and Human Rights: Implementing the United Nations 'Protect, Respect and Remedy' Framework (the Guiding Principles on B\&HR), which were fully endorsed by the UN Human Rights Council. The Guiding Principles on B\&HR, like the Guiding Principles on Internal Displacement, are not legally binding but are consistent with international human rights and humanitarian law standards. The Guiding Principles on B\&HR establish two major steps that companies should take to ensure respecting human rights. First, the business must establish a policy that articulates its responsibility to respect human rights. The policy serves to let employees, investors and the public, among others, know that the company has made a commitment to respect human rights. The process of creating the policy can foster a greater integration of the principle of human rights into the company's day-to-day practices and operations.

The second step is the establishment of a human rights 'due diligence process'a term borrowed and extended from a usage in the corporate world to refer to investigation of a company to ensure that it has no hidden liabilities, including financial, legal, health and safety or environmental problems - which should include four components. Firstly, a company must either augment its current due diligence process or create a new process to identify the people who may be affected by its activities and what rights are being or might be affected by the company's activities. The company then needs to determine what actions to take to remedy its adverse human rights impacts and to prevent or mitigate potential impacts. The company will also need to track or monitor how it responds to actual and potential human rights impacts in order to gauge and improve the effectiveness of its responses. Finally, the company needs to communicate information about the actions it has taken, or intends to take, regarding affected or potentially affected persons to these persons and others, such as shareholders and the public. A company should initiate due diligence with an assessment of its own actual and potential adverse effects on human rights. $^{35}$

\section{CONCLUSION}

Indonesia's National Strategic Project has created an impact of human rights violation and development-induced displacement. The impact spurs problem for local residents who lived in the strategic project area. Thus, it will in turn cause a new poverty through displacement risks including landlessness, joblessness, and marginalization at local level. Findings from Kulon Progo's NYIA airport as case study of the strategic project describe a devastating situation. As NYIA will be built on farming area, the airport will affect agriculture workers and expropriate their economic opportunities and livelihoods. This project is also conducted through weak

35 Corinne Lewis, "Businesses' human rights responsibilities” (2012) 1:41 Forced Migration Review. 
regulations and in draconian way. It is because a lot of regulation required for development project is neglected and attuned to comply with the strategic project.

Furthermore, policy formulation for the strategic project should really consider law and regulation both national and local as well as measure cause and consequence of the strategic project. In terms of implementation, compensation programme is very crucial as this will determine the prosperity of affected residents. Compensation programme must equally fulfil the loss of displaced people otherwise the socioeconomic level of displaced people continued to decline. Moreover, the policy of business enterprises that respect human rights has to support this compensation programme. For Indonesian policy makers, it also relevant to use human right approach and do human rights 'due diligence process' for the perfect mitigation. Then, it is important to involve local residents in the resettlement process by facilitating them in decision making for resettlement programme. As a result of doing this, the resettlement process will run more smoothly, and people aspiration will be accommodated.

\section{BIBLIOGRAPHY}

Aneesh, TV \& R R Patil, "Development and Displacement in Kerala: An Experience of Cochin International Airport Limited (CIAL)" (2015) 11:10 European Scientific Journal, ESJ.

Bhattacharya, Prabhat et al, "Development-Induced Displacement and Human Development Through Industrialisation In India” (2013) 2013 1-5.

Blume, Lorenz \& Stefan Voigt, "The Economic Effects of Human Rights” (2007) 60:4 Kyklos 509-538.

Cernea, Michael M, "Understanding and Preventing Impoverishment from Displacement: Reflections on the State of Knowledge *” (1995) 8:3 Journal of Refugee Studies 245-264.

—, Michael M, The Economics of Involuntary Resettlement: Questions and Challenges (Washington DC: The World Bank, 1999).

Downing, Theodore, "Avoiding new poverty: Mining induced displacement and resettlement” (2002) 1 IDNR- Global Network in Displacement and Resettlement Research 5-8.

- "Creating poverty: The flawed economic logic of the world bank's revised involuntary resettlement policy” (2002) 12 Forced Migration Review 13-14.

__, "Mitigating Social Impoverishment when People are Involuntarily Displaced ( 1” (1996) 2 Understanding impoverishment: The consequences of development-induced displacement 33-48.

Fiala, Nathan, The Economic Consequences of Forced Displacement, HiCN Working Paper, by Nathan Fiala, HiCN Working Paper 137 (Households in Conflict Network, 2009).Indonesia, Government Regulation No. 27/2012 on Environmental Permit 
Indonesia, Law Number 2/2012 on Land Procurement for Development for Public Interest

Indonesia, Law Number 5/1960 on Basic Agrarian Principles

Indonesia, Law Number 102/2016 on Land Procurement for Development for General Interest in Accordance with Implementation of National Strategic Project

Indonesia, Presidential Decree Number 56/2017 on The Mitigation of Social Impact of Land Procurement

Indonesia, Presidential Decree Number 58/2017 on The Amendment to Presidential Decree Number $3 / 2016$ on The Acceleration of The Implementation of National Strategic Project

Kamaluddin, Nurul Kharismawati, "Impact of The Airport Development Process in Kulon Progo” (2019) Universitas Muhammadiyah Yogyakarta.

Knox, John H, "The Myth and Reality of Transboundary Environmental Impact Assessment" (2002) 96 American Journal of International Law 291-319.

Lewis, Corinne, "Businesses' human rights responsibilities" (2012) 1:41 Forced Migration Review.

Meth, Paula \& Glyn Williams, "Literature Reviews and Bibliographic Searches" in Vandana Desai \& Robert Potter, eds, Doing Development Research, 3d ed (London: SAGE Publications, 2006) 560.

PWPP-KP (Paguyuban Warga Penolak Penggusuran - Kulon Progo), A Call for Solidarity: Supporting Struggle of Kulon Progo's Peasant in Fighting Airport and Airport City, by PWPP-KP (Paguyuban Warga Penolak Penggusuran Kulon Progo) (Kulon Progo, Indonesia, 2017).

Ruggie, J \& OHCHR, Guiding Principles on Business and Human Rights: Implementing the UN "Protect, Respect and Remedy" Framework, Report of the Special Representative of the Secretary General on the issue of human rights and transnational corporations and other business enterprises, by $\mathbf{J}$ Ruggie \& OHCHR, Report of the Special Representative of the Secretary General on the issue of human rights and transnational corporations and other business enterprises (2011).

Sen, Amartya, Development as Freedom, Development in Practice 10 (Oxford, 2000).

Sunardi et al, "Livelihood status of resettlers affected by the Saguling Dam project, 25 years after inundation" (2013) 29:1 International Journal of Water Resources Development 25-34.

Terminski, Bogumil, Development-Induced Displacement and Resettlement: Theoretical Frameworks and Current Challenges (Development, 2013).

Ty, Pham Huu, A C M Van Westen \& Annelies Zoomers, "Compensation and Resettlement Policies after Compulsory Land Acquisition for Hydropower Development in Vietnam: Policy and Practice” (2013) 2:4 Land 678-704. 
Sekar Banjaran Aji is a lawyer and former business and human rights researcher of The Institute for Policy Research and Advocacy (ELSAM) who also involved in advocacy day to day to support marginalized people affected by corporations. She was graduated from the Faculty of Law of Universitas Gadjah Mada with specifications on environmental law. She is also alumni of the Business, Conflict \& Peacebuilding Course 2018 Program from Swisspeace \& University of Basel. She is interested in business and human rights, climate litigation, and feminist political ecology.

Achmad Firas Khudi is a master student of social science (development studies) at Chiang Mai University and an urban scholar with a previous bachelor and master's in development economics. He joined other academic events with NIU, the University of Pisa, NUS, and the Association for Asian Studies. He focuses currently on thesis research of Jagged City: Habitable Conditions for Akuarium and Betawi People in Jakarta. Besides, his consultancy was in urban and development with Indonesia's Planning Agency/Bappenas, World Bank, and European Union. Twelve Indonesian cities, including Jakarta and Ternate, and the Thailand plastic are his works. 